\title{
The China-Philippines South China Sea Dispute: A Selective Critique of the PCA Award
}

\author{
Proshanto K. Mukherjee1,2, Huiru Liư3, Minna Yu ${ }^{4 *}$ \\ ${ }^{1}$ Dalian Maritime University, Dalian, China \\ ${ }^{2}$ World Maritime University, Malmö, Sweden \\ ${ }^{3}$ Chinese Research Institute of Civil Aviation Science and Technology, Beijing, China \\ ${ }^{4}$ Ocean University of China, Qingdao, China \\ Email: proshanto.mukherjee@yahoo.com, ${ }^{*}$ yuminna@ouc.edu.cn
}

How to cite this paper: Mukherjee, P. K., Liu, H. R., \& Yu, M. N. (2021). The ChinaPhilippines South China Sea Dispute: A Selective Critique of the PCA Award. Beijing Law Review, 12, 650-676. https://doi.org/10.4236/blr.2021.122035

Received: May 28, 2021

Accepted: June 19, 2021

Published: June 22, 2021

Copyright (c) 2021 by author(s) and Scientific Research Publishing Inc. This work is licensed under the Creative Commons Attribution International License (CC BY 4.0).

http://creativecommons.org/licenses/by/4.0/

(c) (i) Open Access

\begin{abstract}
This article is a critique of selected issues of the Award handed down by the Permanent Court of Arbitration, referred to as "PCA" or "the Tribunal", in the 2016 Philippines-China Arbitration. It points out that the Award was entirely in favour of the Philippines which had unilaterally initiated the arbitration; no regard whatsoever was paid to the position of China as expressed in various official Government documents. China refused to participate in the arbitration proceedings on the grounds that by written declaration it had withdrawn from the compulsory procedures for dispute resolution set out in the United Nations Convention on the Law of the Sea, 1982 (UNCLOS). As such, China rejects the legal validity of the Award and has declared it to be unenforceable. In this article, the doctrinal research method is employed to carry out a comparative analysis of the opinion expressed by the Tribunal and the position adopted by China in terms of the interpretation and application of Article 298(1), in relation to China's withdrawal from the procedures provided in Section 2 of Part XV. Since the publication of the Award, a significant amount of legal literature has been produced, much of which is supportive of the Award. This article presents an alternative viewpoint from a Chinese perspective. It is submitted in unison with the Chinese position that the Tribunal lacked jurisdiction to undertake the arbitration. The article selectively discusses the Chinese position based on China's perception of historical title over the maritime features in the South China Sea and its view that the dispute concerns sovereignty over those maritime features which is outside the scope of UNCLOS. The article concludes that its aim is to underscore the need for an objective and unbiased approach to dispute resolution by tribunals in the field of international sea law and that the better way forward for both states is to continue negotiations.
\end{abstract}




\section{Keywords}

South China Sea Arbitration, China-Philippines, Jurisdiction, Historic Title, Sovereignty

\section{Introduction}

After prolonged deliberation, on 12 July, 2016, the Permanent Court of Arbitration (PCA $)^{1}$ handed down the Award on the merits, herein referred to as "the Award", in the arbitration concerning the dispute between the People's Republic of China and the Republic of the Philippines. The Award is entirely in favour of the Philippines and totally against China which is somewhat uncharacteristic of decisions of international tribunals which tend to adopt a functionally compromising approach to foster cooperation between states involved in such disputes (Bangladesh v. Myanmar, 2012), Costa Rica v. Nicaragua (2013)². The proceedings were commenced by the Philippines pursuant to certain provisions, general and specific, of Part XV and Annex VII to the United Nations Convention on the Law of the Sea, 1982, hereafter referred to as UNCLOS or "the Convention". Incidentally, both China and the Philippines are parties to the Convention. Noteworthy in the present context, is that the Philippines invoked Article 287(1)(c) in choosing the PCA for the settlement of this dispute and in its turn, China invoked a specific element of Article 298(1)(a) to refute that choice. A significant observation in light of the change of Filipino leadership in the post-Award period is that initially a tangential turn in political posture and outreach of the Philippines towards China was apparent which unexpectedly seems to have dissipated lately ${ }^{3}$. China, on the other hand, responded enthusiastically to the earlier positive stance adopted by the Philippines (Thayer, 2017).

A considerable amount of literature has been generated on the substantive merits as well as the jurisdictional aspects of the Award. Some are of western vintage or otherwise reflect a bias in favour of the pro-Philippines stance taken by the Tribunal; Oxman, (2016-2017); Yen, (2017); Chang, (2016); Kopela, (2017); Rossi, (2017); others are works of western and Chinese scholars projecting a neutral or opposite viewpoint. Talmon, (2017); Nordquist, Moore, and Long (Eds), (2017); Zou, (2017); Whomersley, (2017). The main purpose of the present article is to bring to light the Chinese legal perspective, devoid of any political ideology and focusing selectively on certain issues of fundamental importance. The issues selected for analytical treatment are the Chinese stance on the PCA's jurisdiction and the phenomena of historic title and sovereignty in the law of the

\footnotetext{
${ }^{1}$ Alternatively referred to as "the Tribunal" in this article.

${ }^{2}$ See for example, the decision of the International Tribunal for the Law of the Sea (ITLOS) in the Bangladesh v. Myanmar maritime boundary litigation. ITLOS Case No 16; 52014XC0830(01); ICGJ 448 (ITLOS 2012), 14 March 2012. See also the Costa Rica v. Nicaragua decision rendered by the International Court of Justice (ICJ) [2013] ICJ Rep 354; ICGJ 475 (ICJ 2013), 22 November 2013. ${ }^{3}$ https://amti.csis.org/after-four-years-the-philippines-acknowledges-the-2016-arbitral-tribunal-awa $\underline{\mathrm{rd} /}$
} 
sea. Thus, the discussion represents a rebalanced perspective presented from the vantage point of China with arguments and information extracted from public documents available in English and some translated from the Chinese. Much of the material is taken from the published Award of the PCA and the so-called White Paper of the Government of China ${ }^{4}$. Needless to say, the objective is to engage in an academic legal discourse without the taint of any political or ideological considerations.

The analysis presented invariably involves applications of some principles belonging to the broader arena of private law that are germane to the discussion. Furthermore, it is predicated on the necessity of even-handedness as a parameter of the equitable dimension of interstate dispute resolution in decisions and awards of international tribunals entrusted with matters of serious national concerns.

The geographical configuration of the various islands in the South China Sea is of importance in the understanding of the dispute between the Philippines and China which has engendered much rhetoric and legal hostility. China's position is that these differences can be resolved through negotiation and cooperation which can result in mutual benefit. Some peripheral discussion at least is thus warranted on these maritime features. In the Award itself, some 29 features are mentioned and identified, some by their Chinese and Filipino name and others by their English counterpart names ${ }^{5}$. For starters, it is noted that Nanhai Zhudao is the Chinese name for what is otherwise known as the South Chins Seas. It is basically a cluster of maritime features comprising inter alia, islands, reefs, shoals, cays and low tide elevations, otherwise known as drying reefs in nautical jargon. Within the cluster, there are four groupings identified in English as North, South, East and Central, depending on where they are located ${ }^{6}$. The dispute between China and the Philippines centres on the Nansha Qundao (Islands) in the South.

In view of the subject matter of the article being an arbitral award as distinguished from a judicial decision, it is expedient to probe into the phenomenon of arbitration, in particular, from the perspective of inter-state disputes and the role of an international arbitral tribunal. This begs the question of the status of the PCA in international law and its historical evolution. It also raises the issue of its jurisdiction under UNCLOS which is tied to the perceived right of the Philippines to go to arbitration. The jurisdictional question pertaining to the PCA is of particular importance and significance given China's invocation of the relevant UNCLOS provision to extricate itself from the compulsory procedures entrenched in the Convention regarding dispute resolution. China's disengagement from these procedures centres on the paramount issue of national sovereignty over certain maritime features referred to in the article, and then to the

${ }^{4}$ The State Council Information Office of the PRC, "China Adheres to the Position of Settling Through Negotiation the Relevant Disputes Between China and the Philippines in the South China Sea”, July 13 2016, available at http://www.china.org.cn/government/whitepaper/node 7239601.htm. (Chinese White Paper)

${ }^{5}$ See pp. xix-xx of the Award.

${ }^{6}$ Paragraphs 1 and 2 of the Chinese White Paper cited in supra, note 8. 
crucial legal stance regarding its claim to historic title to which the connotation of "entitlement" is inextricably connected.

In conclusion, a summary is presented of the salient issues discussed in the article and pointing to the way forward in recognition of the inevitable unenforceability of the Award.

\section{Arbitration in International Disputes}

Among the reasons why parties involved in legal disputes opt for arbitration over litigation are expediency and cost of proceedings, and the availability of specialist expertise. It is trite that expediency and expertise are the hallmark attributes of arbitration tribunals whether in the public or private law spheres of dispute resolution. Furthermore, in arbitration there is considerable procedural flexibility which is absent in judicial proceedings ${ }^{7}$. Courts in every domain are notoriously rigid in terms of strictures of process which often result in the inordinate and unabated consumption of time and effort which are frequently of the essence when legal disputes need to be resolved. Apart from these considerations, an overarching factor of importance is that as an established norm of law and practice, arbitration is by mutual agreement of the parties in dispute who enter into it by volition. Indeed, at the very core of arbitration as a dispute settlement method lies the phenomenon of consensuality. It has been stated by the Permanent Court of International Justice (PCIJ) that "[A]rbitration is essentially a consensual procedure," (Status of Eastern Carelia, Advisory Opinion, 1923) and in one well-known text it has been pointed out unequivocally in the context of public international law, that "States cannot be compelled to arbitrate unless they agree to do so, either generally and in advance, or ad hoc in regard to a specific dispute. Their consent even governs the nature of the tribunal established". (Starke, 1989).

In most domestic jurisdictions, a plaintiff can bring an action unilaterally against a defendant who is named in the writ or equivalent document of process, and if the defendant fails to appear in court, a default judgment can be entered in favour of the plaintiff. By contrast, whereas in arbitration proceedings, there is no concept of default judgment as such, similar action can ensue but only if a party after agreeing to arbitrate a dispute fails to make an appearance. Thus, indubitably, there is no room for unilateral arbitral action in the domestic law arena in the absence of mutual agreement to arbitrate.

Insofar as treaties are concerned, parties have in law, agreed to be bound by its terms; and if a term provides expressly or by implication, that a party seeking to resolve a dispute through arbitration can do so unilaterally, then arguably, it can proceed uninhibited. However, the counterargument is that in the absence of any express statement to the contrary, a state party can only proceed to arbitration subject to mutual agreement with the party with which it has a dispute. The Philippines obviously assumed that it could opt for arbitration under Article

${ }^{7}$ In historical terms, it is recorded that arbitration as a dispute settlement device existed in ancient China. https://www.icj-cij.org/en/history. 
287(1) (c) as a choice of procedure, without the compulsion of seeking China's agreement to do so. In the observation of the present authors, that might be manifestly unacceptable at law although some might opine that whether or not that is the case is an open question. That the Convention does not expressly state that no mutual agreement is required may be viewed as a deficiency. Indeed, the Convention permits the going ahead of arbitral proceedings and the handing down of an award by the tribunal regardless of the non-appearance or refusal of the other party to participate ${ }^{8}$. It would appear that in this respect, UNCLOS is somewhat peculiar and without precedent in the wider realm of international treaties. Needless to say, the Philippines took strategic advantage of this anomaly unhesitatingly. It is notable in this context that agreement of parties is not solely the province of arbitration law and practice; it exists in judicial proceedings as well as exemplified in the Aegean Sea Continental Shelf Case (Greece v. Turkey, 1977). In that case, Greece claimed that a Prime Ministerial Communique between the two parties, had directly conferred jurisdiction on the International Court of Justice (ICJ) to adjudicate the matter if Turkey refused to enter into an agreement to implement the Communique. It was submitted by Turkey that the Communique was not an agreement, which the ICJ accepted and consequently declined jurisdiction (Johnson' 1976-77).

In the China-Philippines Arbitration, the Tribunal was seemingly under the impression that it could not hand down a decision in default if China refused to participate in the proceedings or otherwise failed to appear. It stated in the Award that the Tribunal has a "special responsibility"; presumably therefore, "It cannot, in China's absence, simply accept the Philippines' claim or enter a default judgment." Yet, that is exactly what the Tribunal did, demonstrating a manifest contradiction in its approach. In relation to the issue of default judgement as it pertained to this case, the observation of one well-known author is quite insightful as quoted below:

In a domestic law case where a defendant refuses to appear the result is a default judgment. In a default judgment case, at least in the United States, the court does not decide the legal issue involved; the winning party obtains a judgment merely because the other party failed to appear. But in the South China Sea arbitration, there could be no default judgment; the tribunal instead had the duty of deciding the legal issues of the case without the benefit of China's counter-arguments. (footnote omitted) This created the task on the part of the Tribunal itself to 'make up' what arguments China could be presumed to make regarding the matter. Then, the tribunal, having formulated these putative Chinese arguments, had the task of evaluating these same arguments against the arguments made by the lawyers for the Philippines, ...The outcome in such a case is not hard to guess. Schoenbaum (2016)

In tandem with his cynical remark, the author points obliquely to a "a whiff of ${ }^{8}$ UNCLOS Part XV, Section 2 and Annex VII Article 9.

${ }^{9}$ Paragraph 12 at p. 4 of the Award. 
unfairness" on the part of the Tribunal (Schoenbaum, 2016). It is obvious from that remark that Professor Schoenbaum the author, considers the stance adopted by the Tribunal as unfair with regard to China but he expresses it is a mild way.

In juxtaposition to the above, it is the view of the present authors regardless of its legality as may be perceived by reference to the relevant UNCLOS provisions, unilateral action as taken by the Philippines and which the Tribunal unhesitatingly heeded, was a travesty of justice. The Tribunal's recognition and admission of the stance adopted by the Philippines was manifestly repugnant to the fundamental tenets of fairness and equity that is central to international law. The supremacy of a state's sovereignty is indubitably acknowledged in international relations in such matters as participation in arbitral proceedings. The default of appearance provision of UNCLOS Annex VII, Article 9 must therefore be subservient to the exercise of sovereignty by a state party to the convention.

In the award, the Tribunal conceded that pursuant to Article 9 of Annex VII of UNCLOS, before making its award, it was bound to satisfy itself that it had jurisdiction over the dispute and that the claim was well-founded in fact and law. As elaborated later in this article, the present authors are of the view that the Tribunal failed to comply with this requirement.

Article 287 (1) of UNCLOS provides for four choices of procedure for the settlement of disputes among state parties to be given by written declaration. The disputes must concern interpretation or application of the convention. Sub-paragraphs (a) and (b) refer respectively to ITLOS and ICJ, both of which are judicial tribunals. By contrast, sub-paragraph (c) refers to an arbitral tribunal constituted according to Annex VII and subparagraph (d) refers to a special tribunal constituted in accordance with Annex VIII. A question arises as to whether judicial and arbitral tribunals should be placed on the same premise in view of the universally recognized principle that arbitration is subject to the parties in dispute agreeing to the applicable procedures and the binding effect of the arbitral award on the parties. If paragraphs 3 and 5 of Article 287 are closely examined, it would appear that arbitration is given more prominence. Under paragraph (3), in the absence of a declaration as mentioned in paragraph (1), arbitration is deemed to be the choice invoked, and under paragraph (5), if the parties opt for different procedures, the dispute must be submitted to arbitration. Arguably, the preference given to arbitration which seemingly allows for unilateral action by a party in dispute, is a downside of the Convention. Needless to note, it was an advantage that the Philippines did not hesitate to grab and the Tribunal wittingly handed down the award, in compliance with Article 9 of Annex VII, although arguably that there was a lack of complete adherence to all the requirements of that provision which will become apparent as the discussion unfolds.

\section{Permanent Court of Arbitration: Status and Standing}

The object of this section of the article is to discuss the origins of the PCA and present the views of the authors regarding its status and standing by reference to 
the opinions of other academics on the matter. It is submitted that conceptually, a court and an arbitral body are contradictions but whatever legal implications that may entail, in the context of Article 287, there is no impediment to a State being free to choose it as a means for dispute settlement.

The Permanent Court of Arbitration (PCA) was established by the Hague Convention for the Pacific Settlement of International Disputes of 1899 adopted by the first Hague Peace Conference of that year ${ }^{10}$. The work of that conference was completed in 1907 pursuant to which another convention was adopted. Prior to these conventions, there was no international tribunal for the resolution of interstate disputes. The members of the PCA were appointed by states parties to one or both of these conventions (Starke, 1989). At its inception, the PCA thus operated as a mechanism for the facilitation of dispute resolution among states in the absence of any other international forum available to serve that purpose. At present, needless to say, that is not the case. Among others, there is the International Court of Justice (ICJ), an organ of the United Nations, and in the maritime field, there is the International Tribunal for the Law of the Sea (ITLOS) established under UNCLOS. The PCA is described as "an institution of a peculiar character", and perhaps cynically, as being "neither 'permanent' nor a court"11. One author of international renown made an insightful comment in a media interview that " $[\mathrm{T}]$ he PCA is not a court. It only provides a registry and secretarial assistance to 'arbitral tribunals constituted to resolve specific disputes' for a fee" (Nordquist, 2016). A court is essentially and indubitably, a judicial tribunal whose legal mandate, powers and functions are defined by national or international legislation, as the case may be. The ICJ is governed by its statute and its predecessor, the Permanent Court of International Justice (PCIJ) similarly functioned under its own statute ${ }^{12}$.

J.G. Starke has remarked that judges as adjudicators operate within "the ambit of established rules of procedure"; in contrast, arbitrators function within an environment of compromise in which they tend to act as "negotiators, or diplomatic agents rather than judges on questions of fact and law". He reiterates that an arbitral tribunal is not a court of law because it can only operate pursuant to the parties agreeing to submit their dispute to it. The practice and procedure in so far as international arbitration is concerned, are no different from their counterpart in municipal law. They are characterized by flexibility and generally without compulsion on adherence to the strictures of law (Starke, 1989). The arbitrators are a "panel of competent lawyers" chosen from the membership of the PCA. When the tribunal is created it operates in accordance with an arbitration agreement, otherwise known as a compromis. The agreement specifies the subject matter of the dispute and the time allocated for appointing the members of the tribunal. It also defines the jurisdiction of the tribunal and prescribes the

\footnotetext{
${ }^{10} \mathrm{https}: / /$ www.spacelegalissues.com/the-permanent-court-of-arbitration/

${ }^{11}$ https://www.dfa.ie/our-role-policies/international-priorities/international-law/courts-tribunals-dis pute-mechanisms/permanent-court-of-arbitration/. See also ibid.

${ }^{12}$ See https://www.refworld.org/docid/40421d5e4.html; Starke, (1989) at p. 488.
} 
procedure to be followed as well as the legal rules and principles on which its decision is to be based. It seems the members never actually meet as a tribunal and apparently, the PCA itself as an entity has no independent jurisdiction as such apart from whatever is accorded to it by the compromise (Starke, 1989). Furthermore, it is stated in reference to the arbitrators that "[T]heir sole function... is to be available for service as members of tribunals which may be created when they are invited to undertake such service" (Hudson, 1944).

In light of the above observations, whether the PCA possesses the credentials to arbitrate interstate disputes in the international arena unless the parties concerned agree to submit to it, may be brought into question. Its status may be considered dubious in the absence of an authoritative competent international body such as the United Nations standing behind it as in the case of the ICJ. Such contention may, however, be refuted in light of Article 4(1) of the Statute of the ICJ which provides as follows:

The members of the Court shall be elected by the General Assembly and by the Security Council from a list of persons nominated by the national groups in the Permanent Court of Arbitration, ... ${ }^{13}$

Furthermore, Article 287 of UNCLOS, provides that a state party has the option of choosing arbitration as one of the compulsory procedures for resolving a dispute provided the arbitral tribunal is constituted according to Annex VII of the Convention. There is no specific mention of the PCA; indeed, no particular arbitral tribunal is mentioned in Article 287(1); nor is any limitation placed on the party's freedom to choose whichever tribunal it desires. Sub-paragraph (d) of that provision simply states-“an arbitral tribunal constituted in accordance with Annex VII".

Incidentally, the Award has been hailed as "a landmark judgement that breaks new ground" and "surely the most important set of jurisprudential rulings in the modern history of the international law of the sea" (Schoenbaum, 2016). It is contextually notable that most of the arbitrators were ITLOS judges but they were not acting in that capacity in this arbitration but rather in their personal capacities. It is therefore submitted that the Award does not count as ITLOS jurisprudence, but it adds to the body of international jurisprudence on the subject no less than if the Tribunal were constituted differently or did not operate under the PCA mantle, which it invariably did. Indeed, the PCA has, to its credit, handed down several awards that are considered to be of distinction in the field of sea boundary disputes between states (Grisbådarna Case, 1909).

Be that as it may, whether the Award qualifies as a source of international law is another question. In this regard, it is noteworthy that the Statute of the ICJ in Article 38(1) recognizes judicial decisions as a source of such law, albeit of subsidiary status. No mention is made of arbitral decisions being a source of law. At any rate, Article 38(1) seemingly applies only in respect of cases before the ICJ (Starke, 1989). Indeed, one author has opined "arbitral awards are not a source of international law; at best they are a subsidiary means of determination of the ${ }^{13}$ https://www.icj-cij.org/en/statute. 
rules of international law". Thus, they cannot be considered as conclusive statements of law (Talmon, 2017). In following that line of argument, the present authors would conclude that the South China Sea Arbitral Award cannot serve as a precedent for any arbitration tribunal acting under Annex VII of UNCLOS; nor for ICJ or ITLOS in respect of the application or interpretation of UNCLOS provisions. In that vein, it may be further concluded that the Award does not contribute to the jurisprudence on law of the sea matters within or outside the perimeter of UNCLOS in any meaningful way.

\section{Jurisdiction of the PCA}

Whether in this case, the PCA had any jurisdiction in the first place is a question that needs to be addressed at the outset of any further discussion. China vociferously claims that it does not $^{14}$. One author, citing Article 288 of UNCLOS, has listed some twelve reasons in support of the Chinese position why the Tribunal had no jurisdiction to deliberate on this dispute. Not all of those reasons are pertain to the present discussion given the selective issues addressed in this article, but two general and three specific ones are indeed relevant (Yee, 2014). Whether China's contention in this regard is supportable at law requires close examination. If indeed it transpires from a robust analysis of the Award that the Tribunal lacked jurisdiction, then regardless of what it decided, the arbitral process was a veritable non-starter.

Prior to the handing down of the Award on the merits, the PCA had already issued its Award on Jurisdiction on 29 October 2015 which addressed matters that were considered to be "preliminary" in scope. In the Award on the Merits, with which this article is concerned, the Tribunal proceeded to deal with outstanding matters of jurisdiction which were not entirely or exclusively of a preliminary character ${ }^{15}$. These were ostensibly the residuals pertaining to its jurisdiction which had not been addressed in its earlier deliberation.

\subsection{Right of the Philippines to Start Arbitration Proceedings}

A crucial preliminary matter concerns the right of the Philippines to commence arbitral proceedings unilaterally against China. In the view of the present authors, for reasons which are expounded below, no such right prevailed in law in favour of the Philippines. That in itself should have been grounds enough for the Tribunal to decline jurisdiction; but instead, it succumbed to the unilateral posture adopted by the Philippines. It completely ignored China's well-documented publicly available legal position that the matter was outside the scope of UNCLOS as it was a dispute involving territorial sovereignty ${ }^{16}$. It needs no reiteration that the Convention does not address questions of disputed territoriality and sovereignty

\footnotetext{
${ }^{14}$ See paragraph 120 of the Chinese White Paper cited in supra, note 8.

${ }^{15}$ This is stated in Item $\mathrm{H}$ of paragraph 60 of the Award at p. 20.

${ }^{16}$ See "Position Paper of the Government of the People's Republic of China on the Matter of Jurisdiction in the South China Sea Arbitration Initiated by the Republic of the Philippines" of the Ministry of Foreign Affairs of the PRC, dated 7 December 2014, http://www.fmprc.gov.cn/mfa_eng/zxxx_662805/t1217147.shtml, retrieved on 24 May 2021.
} 
over maritime features and the present article is not concerned with any contesting arguments on that front. Undoubtedly, at the core of the dispute between the two states, lies the issue of territorial sovereignty over several maritime features, but at least from the Chinese perspective, there is reason to anticipate its resolution through negotiation ${ }^{17}$.

Regardless of such expectations which may or may not eventually materialize, the point about the Tribunal's exercising of jurisdiction is that it was manifestly contrary to the position taken by China through its invocation of Article 298(1)(a) of UNCLOS. Embedded in that provision is the ability of a state party to extricate itself by written declaration, from any procedure set out in Section 2 of Part $\mathrm{XV}$ of the Convention, albeit only in respect of disputes set out in sub-paragraph (a)(i). China, in fact, made such written declaration in 2006. Thus, by formally invoking Article 298 paragraph 1(a)(i) it made itself immune to "all compulsory procedures entailing binding decisions" set out in Section 2 of Part XV with respect to disputes concerning, inter alia, sea boundary delimitations and historic titles. In light of such action taken by China fully in accordance with the relevant provisions of the Convention, the initiation of arbitration proceedings by the Philippines should not have been recognized by the Tribunal. China's action should have invariably eliminated the jurisdiction of any tribunal, arbitral or otherwise, to rule on any dispute relating to those matters given that the whole of Section 2 became inapplicable, including the use of the dispute resolution mechanisms in Articles 288(1) and (2).

\subsection{Rationale Underlying the Optional Exceptions, The Chinese Position and Its Non-Recognition by the PCA}

Even though the rationale submitted below is admittedly speculative, one may ponder over why these optional exceptions provided in Article 298 were created in the first place. The framers of the Convention must have realized the potential consequences of imposing compulsory procedures on states compelling them to submit to judicial or arbitral proceedings. It would be viewed as a veritable impingement on their sovereignty and the Convention might have faced the risk of states refusing to join it after almost a whole decade of arduous negotiations leading to its adoption. Its architects, in their wisdom, thus produced a wellcrafted exception by way of Article 298. It appears that at the diplomatic conference when the Convention was being negotiated, participants realized that "certain matters were so sensitive that they should not be subject to compulsory and binding dispute settlement procedures being envisaged for inclusion in the Convention." Zou and Ye, (2017). In this context, there is further scholarly opinion suggesting that “...the optional exceptions (Article 298) purports to restrict the applicability of the radical principle of compulsory settlement in particular situations, thereby excluding certain cases from the reach of Part XV courts and tribunals" (Allen, 2017). These are insightful remarks which at least obliquely point to the conclusion that the object of the optional exceptions in Article 298

\footnotetext{
${ }^{17}$ See excerpt from Xu, reproduced in paragraph 96 at pp. 32-g33 of the Award.
} 
was not for tribunals to undo or negate its effectuation or deprive a state party of its right to invoke it, and defeat its intended purpose.

Perhaps unsurprisingly, however, the PCA refused to recognize the validity of China's invocation of the Article 298 exception. It was of the opinion that the dispute did not involve "sea boundary delimitations" and that China's claim to "historic title" was legally invalid, and concluded that it possessed jurisdiction under Section 2 of Part XV to pass judgement. In the view of the present authors, both grounds for asserting jurisdiction were unsound, to say the least. In the exposé below, the second ground is critically and analytically examined.

First, attention is drawn to the specific words in the chapeau to subparagraph (a)(i) in paragraph 1. They are "... a State may (emphasis added), without prejudice to the obligations arising under Section 1, declare in writing that it does not accept any one or more of the following categories of disputes" in Article 298(1)(a)(i). Clearly, the word "may" as emphasized above, denotes that it is a prerogative of a state to make or not make such a declaration as provided in the sub-paragraph (Mukherjee, 2021) ${ }^{18}$. In other words, regardless of whether another state party to the Convention disagrees with or objects to the basis on which a declaration is made, no such state can prevent the declaring state from exercising that prerogative; nor can any tribunal, judicial or arbitral, disenfranchise a state from doing so. Second, and further to the first point, withdrawing from the clutches of compulsory submission to any kind of procedures by written declaration, particularly where the Convention provides for it, is indisputably a sovereign act of the state concerned. It is submitted by the present authors that no adjudicatory body can deprive a state of the prerogative to make that choice or dictate to it whether it can or cannot make such a declaration. In the same vein, no tribunal can have jurisdiction to rule on the validity of such declaration.

The rationale for the above conclusion of the authors is three-fold. The first is predicated on the word "optional" which appears as an adjective to the word "exceptions" in the heading of Article 298. The plain meaning of "option" is choice; in other words, states have the right to choose not to be bound by the compulsory procedures of Section 2. In essence, the choice is a sovereign prerogative of that state, and once it is made, it is a foregone conclusion over which no adjudicatory body can then pass judgment on its validity made by statutory declaration. If it were otherwise, there would be a contradiction in terms, which could not have been intended by the drafters. Clearly, the object of affording that choice is to ward off any adjudicatory intrusion into the arena of state sovereignty manifested through it.

Secondly, on the other hand, there is the question of whether the exercise of that sovereign prerogative is unrestrained. No doubt, appropriate consideration must be given to the principle of international comity or the doctrines of sovereign equality and equity inherent in international law. But even so, it is not

${ }^{18}$ In terms of statutory construction, the word "may" in Article 298 (1) means there is a right to make a choice or exercise an option. See Mukherjee, (2021) at p.116 where it is stated that the word "may" can be used inter alia, "in the sense of... providing an option". 
within the province of an adjudicatory body to pass judgment on the validity of a state's choice. Indeed, if any such right exists, it must only belong to other state parties to decide whether or not to recognize it or challenge its legal validity. The downside of that proposition is that if other states disagree, the matter is liable to return to the dispute resolution mechanisms in the Convention which may be undesirable. Here, the third question or consideration crystallizes, namely, whether adjudicatory intervention to rule on the legal validity of the declaration was contemplated by the architects of the Convention.

The answer to whether the rightness or wrongness of the choice expressed by a state through a statutory declaration be questioned at all lies in Article 298(1)(a) itself where it is stated that if no agreement between the parties is reached within a "reasonable period of time", any one of them may unilaterally invoke the application of Section 2 of Annex V and submit the dispute to compulsory conciliation. In those circumstances, the state which has made the declaration must accept the submission of the matter to such conciliation. Clearly, the aim of conciliation is to reach an amicable settlement ${ }^{19}$; and it is notable in that regard that any reference to adjudication by an arbitral or judicial tribunal, is conspicuous by its absence. It is thus apparent that the drafters of the Convention consciously avoided providing for any form of adjudication that may constrain or deprive a state party from exercising a sovereign prerogative afforded under the Convention, namely, the choice of refusing to submit itself to any compulsory procedures.

That said, whether or not "a reasonable period of time" had passed for the compulsory conciliation provision to be activated, must surely be determined objectively. From the Chinese perspective, it would seem that reasonable time had not passed because both China and the Philippines had contemplated negotiations would continue, as reported in the Award itself $f^{20}$. Incidentally, Article 298(1)(a)(i) provides that in the event of concurrent consideration of an unresolved dispute regarding rights of sovereignty over continental or insular land territory, application of the compulsory conciliation requirements is excluded. It is clear from this provision, among others, that the drafters intended to promote and foster peaceful negotiation between the disputing parties ${ }^{21}$. The PCA seems to have overlooked this matter of considerable importance in international relations. It unabashedly asserted jurisdiction and rushed into the merits of the case.

\subsection{Concluding Remarks Regarding the Tribunal's Jurisdiction}

The main conclusion emerging from the foregoing analysis is that the PCA had erred in asserting jurisdiction in the face of China extricating itself from the compulsory procedures of Section 2 of Part XV of the Convention. In tandem with that, the Tribunal lacked jurisdiction to pass judgment on the legal validity

\footnotetext{
${ }^{19}$ UNCLOS Annex V Article 5.

${ }^{20}$ Written representations made by China reported in paragraphs 96 to 97 at pp. 33 and 34 of the Award.

${ }^{21}$ Second proviso in Article 298 (1)(a)(i).
} 
of the written declaration made by China to that effect. It is submitted that the conclusion arrived at is manifestly sound and consistent with the relevant elements of Article 298(1)(a)(i). It is strange that under the caption "Jurisdiction" in the Award, there is no reference to the matters addressed above $e^{22}$, although under the heading "Summary of the Tribunal's Award on Jurisdiction", there is mention of Article 288(4) of UNCLOS which provides that the court or tribunal in question can, "[I]n the event of a dispute", decide whether or not it has jurisdiction to deal with $\mathrm{it}^{23}$, which the PCA did unhesitatingly. It must be noted, however, that in paragraph 4 of Article 288, the word "dispute" is in reference to "dispute as to whether a court or tribunal has jurisdiction", and not necessarily to a "dispute concerning the interpretation or application" of the Convention. Arguably, the phraseology "interpretation or application" may be accommodated within paragraph 4 if an expanded construction is given to it. Be that as it may, most likely, China would consider that provision redundant in light of its adopted legal stance.

Despite the justifications rudely assembled and the plethora of cases cited in the Award ${ }^{24}$, the phrase "[I]n the event of a dispute" discussed in the foregoing text, must be construed in its proper context to activate the application of that provision. In other words, the dispute in question must relate to jurisdiction arising in the context of the proceedings before the Tribunal; proceedings in which China of its own volition in the exercise of its right by virtue of national sovereignty, declined to participate. In relation to that, it is submitted that nonparticipation, or "default of appearance", as that phrase appears in Article 9 of Annex VII, is simply a provision regarding procedure. It has little to do with the expression "event of a dispute" in Article 288(4) which is a substantive provision. Viewed in that light, it is questionable whether the reference in the Award to comments and communications attributed to the Chinese Ambassador mentioned in it, and the Tribunal's considerations of them should be of any legal consequence ${ }^{25}$.

That said, what is certainly relevant in connection with China's refusal to participate in the proceedings, is the requirement in Article 9 of Annex VII to the Convention ${ }^{26}$ specifying the Tribunal's duty to "satisfy itself... that the claim is well founded in fact (emphasis added) and law". It is plainly apparent that whereas the facts presented by the Philippines in support of its claim received full attention, appreciation and endorsement by the PCA, that was woefully missing when it came to the facts supporting and corroborating the Chinese stance in the matter. To ensure that the claim was well-founded in fact, the verity and validity of the facts presented by the Philippines should have been objectively assessed by examining the facts as perceived by China correspondingly. Even though no formal submission of facts was made by China in support of its cause, the facts

\footnotetext{
${ }^{22}$ See pp. 79 and 80 of the Award.

${ }^{23}$ See p. 56 of the Award.

${ }^{24}$ See footnote 70 at p. 56 of the Award.

${ }^{25}$ See paragraphs $145-148$ at pp. 56-57 of the Award.

${ }^{26}$ Mentioned at p. 56, paragraph 145 of the Award.
} 
were publicly available but the Tribunal refused to recognize the information emanating from Chinese sources. In this regard, the even-handedness of the Tribunal must surely be called into question.

A fundamental point with respect to jurisdiction is that a holistic consideration of the dispute first requires the resolution of the issue of territorial sovereignty over the maritime features in question. In this context, it is to be noted that jurisdiction ratione materiae including that related to territorial sovereignty, is generally lacking in UNCLOS which potentially impedes the jurisdiction exercisable by Article 287 tribunals (Nordquist, Nandan, Rosenne (Eds.), 1989). As such, it may be arguable that these tribunals have no connection with the interpretation or application of UNCLOS (Jia, 2014; Boyle, 1997). However, Professor Nordquist points out that even though Article 288(1) limits jurisdiction to disputes involving "interpretation and application" of the Convention, a broad construction of that phrase can ostensibly cover everything in the Convention (Chen, 2016).

\section{Enforceability of the Arbitral Award}

The enforcement of any decision of an international adjudicatory body, whether judicial or arbitral, is fundamentally problematic from a legal viewpoint. This is mainly because of the phenomenon of sovereignty of states in international law and international relations. Whereas in the domestic sphere, there are numerous enforcement bodies including the courts themselves, which possess the requisite powers and the wherewithal to take enforcement action, there is no such independent corresponding mechanism in the international sphere. Enforcement or effectuation of an internationally rendered decision is only possible through the agency of relevant national institutions. A major part of the problem is the absence of a general legal binding force applicable internationally. To enforce legal decisions, non-legal means must be resorted to, such as political or economic sanctions.

Rolling back to the era of the PCIJ and the subsequently the ICJ, a significant observation is Article 59 in the Statutes of both those institutions which state that their decisions have "no binding force except between the parties and in respect of that particular case" (Starke, 1989). Unsurprisingly, arbitration awards, because they flow from agreements between the parties, are unenforceable unless they do so voluntarily. As noted above, internationally, even a judicial decision is only enforceable by volition. Thus, the Award of the PCA can only be enforced if China agrees to abide by it voluntarily, which is most unlikely. Indeed, China has made it abundantly clear through public declarations and communications based on legal grounds that the Award is of no legal consequence and is unenforceable ${ }^{27}$.

\section{The Philippines' Right to Seek Arbitration}

The PCA has stated in the Introduction to the Award that the Philippines com-

${ }^{27}$ See China's concluding remarks in paragraph 120 of the Chinese White Paper in which it is stated in reference to the awards of the Tribunal that "China does not accept or recognize those awards. China opposes and will never accept any claim or action based on those awards." 
menced the arbitration pursuant to Part XV of and Annex VII to UNCLOS ${ }^{28}$. It is presumed that the Philippines invoked paragraph 1(a)(c) of Article 287, but whether it had the right to proceed at all needs to be examined. Article 287 is contained in Section 2 of Part XV which bears the caption "Compulsory Procedures Entailing Binding Decisions". The first Article in this Section is Article 286. It states-“Subject to section 3, any dispute concerning the interpretation or application of the Convention, shall, where no settlement has been reached by recourse to section 1, (emphasis added) be submitted to the court or tribunal having jurisdiction under this section" (meaning section 2)." Undoubtedly, the expression "[S]ubject to section 3" in this Article points to the superior status of Section 3 over Section $2^{29}$.

In reference to the italicized words in Article 286, the material question is whether any settlement had in fact been reached between the parties by recourse to Section 1. The Tribunal obviously assumed that at the time the Philippines decided to proceed unilaterally, no settlement had been reached. There is no doubt that when the Tribunal assumed jurisdiction, no concluded settlement was in place, but there was no evidence either that all possibilities under Section 1 had been exhausted. Incidentally, Article 281(1) which is in Section 1, states that "...the procedures provided for in this Part apply only where no settlement has been reached by recourse to such means and the agreement between the parties does not exclude any further procedure". One author has stated in this regard that "if the parties still continue to continue their diplomatic negotiation or consultation, no compulsory procedure applies" (Jin, 2017). Indeed, recourse to Section 1 was contemplated by the parties to be an on-going process evidenced by the fact that they had agreed in writing to continue peaceful negotiations. In Section III of the Chinese White Paper, China confirms that "the two sides have reached important consensus on settling through negotiation relevant disputes in the South China Sea and properly managing relevant disputes" ${ }^{\prime 30}$. A Chinese Government Official expressed the view_-...given that China and the Philippines have agreed to settle their disputes in the South China Sea through negotiation, the Philippines is precluded from initiating arbitration unilaterally"31. The Tribunal seems to have paid no attention to the fact that negotiations were anticipated to be on-going, and appears to have categorically refused to consider these statements emanating from the Chinese side.

In the opinion of the present authors, if the parties reach a deadlock, it can be assumed that no settlement has been achieved. But that is not the same thing as disagreement that has led the parties to the end of the road with no way left open

\footnotetext{
${ }^{28}$ Paragraph 4 at p. 1 of the Award.

${ }^{29}$ The words "interpretation or application" appearing in several places in the Convention might appear to be indicating a limitation or restriction, but when read together, they can cover the entirety of the Convention. It may be a contention that the phrase simply means "any provision in the Convention".

${ }^{30}$ See paragraph 73 of the Chinese White Paper.

${ }^{31}$ See excerpt from Xu (2016), "Briefing on the South China Sea Arbitration Initiated by the Philippines" reported in paragraph 96 at pp. 32-33 of the Award.
} 
for any further negotiations. Unless the credibility of the Chinese sources were to be completely discredited without any conceivable grounds for doing so, there was nothing indicating that there was no further way ahead. Indeed, it was evident that the parties had not only agreed in writing bilaterally, but had also done so under the auspices of the Association of South East Asian Nations (ASEAN) (Zhang, 2016). In light of the foregoing observations, the irrefutable factual assertions of China were obviously not given any consideration by the Tribunal. It is notable that Article 281(2) in Section 1 refers to a "time-limit" but in that respect there was no evidence that any time-limit had been agreed and that it had expired.

On the whole it appears that in terms of the application of Article 298(1)(a)(i), the cross reference in paragraph 1 to "procedures provided for in Section 2"; and the cross reference in Article 286 of Section 2 to the whole of Section 1 which includes Article 281(2), the Philippines had acted prematurely by moving hastily to initiate arbitral proceedings under Article 287(1)(c). It no doubt concluded that no settlement had been reached under Section 1 ignoring its own agreement with China to negotiate peacefully. That agreement, needless to say, was acknowledgement of the fact that the process to reach a peaceful settlement had not been completed and was still pending.

Having considered the question of the Philippines' right to seek arbitration and given the foregoing view of the present authors, it is expedient to consider on what principal basis did the claim of China rest. This is addressed in the next section.

\section{China's Claim of Historic Title}

At the outset it must be noted that the phenomena of historic title and sovereignty are closely interrelated. Both are constituent elements of Article 298(1)(a)(i) from which China disengaged itself by written declaration. In this discussion, despite their correlation, the two elements are addressed analytically under two separate headings. The first is "historic title" which is subsumed within the concept of "historic rights". As the discussion unfolds, the micro-analysis will expose the intimate connections in substantive as well as semantic terms, among the expressions "historic bays" and "historic title" used in Article 298(1)(a)(i), and "historic rights" used in the Award.

The findings of adjudicatory tribunals, whether judicial or arbitral, national or international, involve the application of the law to facts which come to light in the course of the proceedings, which is turn leads to the decision(s) rendered as judgements or awards. Facts are invariably established through plausible and irrefutable evidence. It is of major significance that the PCA in its arbitral award, rejected China's claim to historic title to certain maritime features in the South China Sea. It denied China's claims of historic title under general international law including its customary law dimension (Ma, 2018; Higgins, 1963). One author has made a scathing remark that the Tribunal misinterpreted China's posi- 
tion with "deliberate ignorance and malicious distortion" (Fu, (Part I), 2019). Thus, the findings of the Tribunal were manifestly erroneous. If the evidence was weighed carefully without any built-in biases, it would have pointed to indisputable facts contrary to the Tribunal's findings.

From the viewpoint of the authors, these are just preliminary thoughts. For a substantive discussion, starting at the rear end of the Award, that is, the so-called Dispositif might be worthwhile. In item $\mathrm{B}(2)$ of the Dispositif it is stated that "the Convention supersedes any historical rights". Expressions almost identical in essence, appear in paragraphs 262 and 263 of the Award ${ }^{32}$. With regard to the use of the term "historic rights", it has been pointed out that the proper term is "historic title" which has been used in two provisions in UNCLOS, namely, Articles 15 and 298(1)(a)(i) (Chen, 2016). Conceptually, "historic rights" encompasses "historic title" signifying a broad inclusive connotation which, as stated by the author Yushifumi Tanaka, can be defined as "rights over certain land or maritime areas acquired by a State through continuous and public usage from time immemorial and acquiescence by other States although these rights would not normally accrue to it under general international law." (Tanaka, 2012). In light of this definition, the pronouncement made by the Tribunal that China's historical rights have been superseded by the Convention, is nothing but presumptuous injudiciousness. There is no provision in the Convention that remotely supports such contention.

Indeed, the norm as reflected in the international law of the sea as it has evolved over centuries, is quite the opposite, namely, that a rule established through convention gives way to historic rights and historic titles; they are recognized as entrenched and unshakeable. One example is Article 12 of the 1958 Geneva Convention on the Territorial Sea and Contiguous Zone ${ }^{33}$ where it is stated in essence that "historic title" is good reason for the rules relating to territorial sea delimitations to not be applicable ${ }^{34}$. Notably, in Tunisia v. Libya (1982), the ICJ held that "Historic titles must enjoy respect and be preserved as they have always been by long usage". A noteworthy point in this regard is the term "historic sovereignty". The Tribunal states that ' $[\mathrm{H}]$ istoric title' is used "specifically to refer to historic sovereignty to land or maritime areas" ${ }^{\prime 35}$. In respect of this term, Professor Keyuan Zou has remarked that its use is "very rare in the literature of international law" as a substitute for "historic title" (Zou, 2016).

Another example where a historic claim is upheld is in the context of "Bays". Paragraph 6 in Article 10 of UNCLOS states unequivocally that the rules concerning bays do not apply to historic bays. There are numerous examples of such historic bays stretching across the globe that do not otherwise qualify as bays according to the Article 10 prescription. Interestingly enough, in a United Nations Secretariat study reference was made to a state which validly claimed, "title

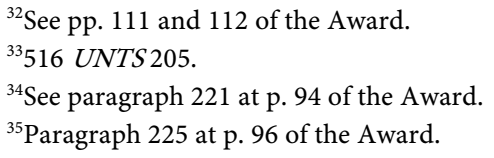


to a bay on historic grounds" (Churchill \& Lowe, 1999).

It is expedient in this context to examine the exact words of Article 298(1)(a)(i) which are "historic bays or titles". Much has been said in the Award about this phrase. The implication with regard to it is that on the one hand, China allegedly claims rights to the living and non-living resources within the "nine-dash line"; on the other hand, the Tribunal understands that China does not consider the waters enclosed by that line to be a part of its territorial seas or internal waters ${ }^{36}$. The Tribunal's stance based on that understanding is contextually innocuous and immaterial. The issue is how the words are to be perceived and construed from the viewpoint of treaty interpretation. The word "those" preceding the phrase "historic bays or titles" evidently generates ambiguity. The Philippines contended that "those" referred to "sea boundary delimitations" with which the Tribunal rightly disagreed. In its opinion, the application of the teleological or "object and purpose" method of interpretation provided in Article 31(1) of the Vienna Convention on the Law of Treaties, 1969, leads to the unequivocal conclusion that the reference is to "disputes" 37 . Having said that, one cannot but notice the needless overload of verbiage in the Award pointing to the multi-lingual character of UNCLOS where in some of the languages including English, the ambiguity is apparent whereas in others including Chinese, the expression is clear enough ${ }^{38}$.

Flowing from the foregoing discourse is an important question as to whether the term "historic title" is synonymous with or akin to "historic rights" noting that the latter is not used in Article 298(1)(a)(i). The Tribunal discussed this issue at length delving into the history of what is "historic" in the context of international law of the sea going beyond UNCLOS. In the course of that discussion, apart from historic bays and historic title, several other terms have been mentioned including historic rights, and historic waters, and the interrelationships between and among them (Ma, 2018). A common denominator is "continuous exercise of the right" by the state claiming it and the corresponding acquiescence of affected states ${ }^{39}$. Regarding historic bays, historic rights and historic waters, references are made to various U.N. and International Law Commission (ILC) Reports pertaining to previous conferences on the subject of law of the sea since the 1930 Hague Conference as well as the 1951 decision of the ICJ in the Anglo-Norwegian Fisheries Case (United Kingdom v. Norway) (1951). Initially, it was "historic bays" which caught the attention of those involved in law of the sea matters, but later it was found that the term "historic" could also apply to "straits, estuaries and other similar bodies of water" giving that word an expanded connotation. Reference was made to "the juridical regime of historic waters" in a Conference Resolution adopted by the diplomatic conference leading up to the 1958 Geneva Convention on the Territorial Sea and

\footnotetext{
${ }^{36}$ Paragraph 214 at p. 91 of the Award.

${ }^{37}$ Paragraph 216 at p. 92 of the Award.

${ }^{38}$ Paragraphs 215 at p. 92 of the Award.

${ }^{39}$ Ibid. at p. 21.
} 
the Contiguous Zone. Apparently, the term "historic title" did not enter the nomenclature of international sea law until the advent of that Convention. But it is instructive to learn that it had been used previously in the Anglo-Norwegian Fisheries Case (United Kingdom v. Norway) (1951).

After reviewing much of the history in the field, the Tribunal made the point that "historic rights" is conceptually wider in scope. The term can accommodate several varieties of rights including sovereign rights ${ }^{40}$ whereas "historic title" is more specific. The word "title' itself, a derivative of "entitlement" is associated with right of ownership or sovereignty over land and maritime areas, akin to proprietary legal interests. In Article 15 of UNCLOS the term "historic title" appears in reference to bilateral boundary delimitation of territorial seas, exemplifying its usage in that sense. The Tribunal then expressed the opinion that "historic title" in Article 298(1)(a)(i) means "claims of sovereignty over maritime areas derived from historical circumstances" toric title" must mean "title to sovereignty" over a maritime feature, (Jia, 2014). which is consistent with China's claim on that score. That said, it is doubtful that the expression "historical circumstances" used by the Tribunal clarifies anything. In terms of its plain or ordinary meaning, "historic" alludes to "historical circumstances". Casting aside the semantic surgery, it is plain that historic title is precisely the ground on which China rests its claim over the subject maritime features in the South China Sea, and the corresponding basis of China's declaration under Article 298(1)(a)(i) withdrawing itself from the application of Section 2 of Part XV of the Convention.

In discrediting China's declaration, the Tribunal resorted to needless verbosity to vigorously assert jurisdiction stating that the provision speaks to disputes involving "historic title", but China has only claimed "a constellation of historic rights short of title", whatever that means. It refers to "entitlements" not acknowledge a claim to "title". With or without semantics, from a philological point of view "entitlement" is derived from the root word "title", and from a legal point of view, it is a right. There is no doubt that China claims sovereignty over the maritime features in the South China Sea ${ }^{43}$; equally, there is no doubt from China's perspective, that the claim is derived from "historical circumstances" as that expression is used by the Tribunal ${ }^{44}$. Indubitably, the claim is one of historic title, regardless of whatever other expressions China may have used in public documents or domestic legislation.

At any rate, at the risk of repetition, it is submitted that the Tribunal had no jurisdiction over matters involving maritime delimitation or historic titles, in view of the declaration made by China in 2006, pursuant to Article 298 (1)(a).

\footnotetext{
${ }^{40}$ The Tribunal in reference to China's claims, mentioned "historic rights or other sovereign rights "in one breath. See paragraph 278 at p.117 of the Award.

${ }^{41}$ Paragraph 226 at p. 96 of the Award.

${ }^{42}$ Paragraph 207 at p. 86 of the Award.

${ }^{43}$ This is acknowledged by the Tribunal in paragraph 206 at p. 86 of the Award. The issue of sovereignty is elaborated later in this article.

${ }^{44}$ Paragraph 226 at p. 96 of the Award.
} 
But it ruled erroneously, in the opinion of the present authors, that China's historic rights were "extinguished by the entry into force of UNCLOS in 1994". (Nordquist, 2016).

Apart from the discourse on "historic rights" and "historic title", it is incumbent on us to examine the evidentiary aspect of the history claimed by China in support of its position. In this regard, there is an abundance of history surrounding the islands of the South China Sea as well as other maritime features. To what extent China's claims are supported by that history is a question of the probative value of that history as plausible evidence ${ }^{45}$. History is supposedly finite but it is likely to evoke debate, controversy and emotion if its rendition and expression is unduly subjective. It is also about facts and therefore objectivity is its very essence. If facts are distorted or even given a makeover, objectivity is lost and the purpose of drawing on history to achieve a defined goal is defeated.

In legal proceedings, whether judicial or arbitral, facts are established by examining evidence and evaluating the probative value of each piece of it which aggregates to conclusive proof. However, evidence is not easy to grapple with as a legal phenomenon. For example, hearsay is inadmissible as evidence but almost everything historical is hearsay, particularly if it is of ancient vintage. Historical evidence constitutes a compilation of facts recorded and preserved over time without distortion or exaggeration. Its verity can only be confirmed, verified and established as conclusively as may be possible, by experts in the field, and its value lies in its proven credibility ${ }^{46}$. It is not a task for lawyers, judges or arbitrators without the requisite expertise of professional historians. Without such skill, the exercise of evaluating historical evidence is reduced to subjective perceptions laced with personal preferences and tempered by biases. The arbiter of facts must reach conclusions by ascertaining the probative value of one piece of historical evidence over another predicated on credibility. On that score, the Tribunal did seek expert advice and opinions, but the extent to which full objectivity was exercised in its deliberations, leaves a shadow of doubt.

Historical evidence made available by China through, maps, charts, and preserved manuscripts of antiquity together with more recent materials such as sailing directions for mariners from Chinese as well as non-Chinese sources, seem to have been consciously rejected by the Tribunal, or sufficient efforts were not expended to obtain them. A considerable amount of historical material was showcased as evidence by the Chinese media but that seemingly failed to attract the Tribunal's attention. But the fact that it viewed "French material" obtained from the National library of France and the French Overseas National Archive ${ }^{47}$, clearly smacks of undue prejudice and a lack of even-handedness.

The Tribunal categorically rejected the entirety of China's claims to historic rights, stating that they were "contrary to the Convention and without lawful effect to the extent that they exceed the geographic and substantive limits of Chi-

\footnotetext{
${ }^{45}$ The Chinese White Paper in paragraphs 8-54 provides a detailed historical account.

${ }^{46}$ See Ibid.

${ }^{47}$ Paragraph 99 at p. 35 of the Award.
} 
na's maritime entitlements under the Convention"; and that "the Convention superseded any historic rights or other sovereign rights or jurisdiction in excess of the limits imposed therein" ${ }^{48}$. The conclusion is, at the least, largely laced with an apprehension of bias. The Tribunal consciously disregarded the fact that the dispute was about sovereignty over certain maritime features which generated the entitlements to which it referred.

\section{Sovereignty as a Central Factor Associated with Historic Title}

As mentioned earlier, China's position with regard to the dispute is that it concerns territorial sovereignty which is beyond the scope of UNCLOS ${ }^{49}$. Indeed, the Tribunal recognized that position on a number of occasions but the end result of the Award was contrary to that stance as opined by the present authors later in this article. One author cited earlier has fervently remarked that "based on its ignorance and biased viewpoints" Fu, (Part II) (2019) the Tribunal has reservedly acknowledged that "historic rights may include sovereignty" 50 . The same author has also pointed out the Tribunal's error in reaching the conclusion that in Article 298(1)(a)(i), "historic title" only (emphasis added by the present authors) means "historical claims of sovereignty over maritime areas", which China never claimed. That author, of course, disagrees and in his publication has unkindly admonished the Tribunal to "read the historical materials" and other official Chinese documents claiming sovereignty over the waters encompassed by the nine-dash line. Fu, (Part II) (2019). He further pointed out that the Tribunal "completely negated China's sovereignty, sovereign rights and jurisdiction" over the relevant areas and exceeded the scope of the claim presented to it by the Philippines (Fu, (Part I), 2019).

Professor Nordquist has rightly and insightfully remarked that UNCLOS represents the international law of the sea no doubt, but there is nothing in the Convention empowering a tribunal to grant sovereignty to any littoral state or to extinguish any sovereignty that already exists over any territory ${ }^{51}$. Such assertion at once raises the question of what sovereignty is exactly. Conceptually and in legal theory, sovereignty derives from the persona of the "sovereign" or ruler who since ancient times has asserted ownership over lands and territories on behalf of the citizens he/she rules whether they are continental, insular or oceanic features. In the marine geosciences maritime features are distinguished as being either continental or oceanic depending on the place from where they originate. The continental shelf, for example is continental, geologically defined as "the natural prolongation of the continental land mass"; whereas seamounts are ocea-

\footnotetext{
${ }^{48}$ Paragraph 278 at p. 117 of the Award.

${ }^{49}$ See excerpt from Xu (2016), "Briefing on the South China Sea Arbitration Initiated by the Philippines" reproduced in paragraph 96 at pp. 32-33 of the Award in which it is stated - "...the essence of the subject-matter of the arbitration is territorial sovereignty over several maritime features in the South China Sea, which is beyond the scope of the UNCLOS".

${ }^{50}$ Paragraph 225 at p. 96 of the Award.

${ }^{51}$ http://www.ipsnews.net/2016/06/china-is-not-getting-a-fair-shake-us-expert-says/
} 
nic as they arise from the seabed (Organization (IHO) publication, 1982).

Sovereignty, as it pertains to public international law, is predicated on the notion of statehood. Thus, a "State" in public international law treaties is usually identified by capitalizing the letter " $\mathrm{S}$ " in that word or casting it in upper case to signify reference to a sovereign state. Also, in that branch of law, regardless of whether or not the " $\mathrm{S}$ " is capitalized, the word "state" is construed differently from words like "country", "principality", "territory", "possession” "colony" and the likes (Starke, 1989).

Conceptually, sovereignty or territorial sovereignty is associated with ownership of features on earth, whether terrestrial (on land) or maritime (at sea). Thus, sovereignty flows from ownership which, in turn, is demonstrated by possession or occupation of land or water that is res nullius, hence the common law adage that "possession is nine-tenths of the law", and the legal principle that possession is prima facie evidence of ownership. These precepts prevail in maritime law as much as they do in the law applicable on terra firma. These fundamental propositions are integral to the basic law of property in virtually all legal systems.

In shipping law, possession is exemplified by the legal doctrine of effective control exemplified by the decision in The Tubantia (1887) where the court held that the plaintiff salvors had possession of the derelict and the defendants had committed trespass by attempting to obstruct the plaintiff's salvage operations (Reeder (Ed.), 2011). In public international law, the private law concept of trespass translates into violation of territorial sovereignty.

Regarding sovereignty it is stated that "sovereignty of a state means the residuum of power which it possesses within the confines laid down by international law." This implies that the state is subordinate to the law of nations, which in a previous era was hailed as a legal norm and part of the jus natural (Starke, 1989). Interestingly, sovereignty is said to be a "term of art rather than a legal expression capable of precise definition". A sovereign independent state possesses the exclusive power "to control its own domestic affairs" and the corresponding duty "not to perform acts of sovereignty on the territory of another state". It is trite, therefore, that territorial sovereignty is the very essence of sovereignty, and a violation of it is tantamount to a violation of the state's sovereignty (Starke, 1989). The decision of the ICJ in the The Corfu Channel Case [1949] is an apt demonstration of this phenomenon. It was held in that case that British minesweeping operations in the territorial seas of Albania in the Corfu Channel constituted a violation of Albanian sovereignty.

It is the considered opinion of the present authors that sovereignty as an international law phenomenon stems from the property law concept of ownership. In other words, in the context of a state, sovereignty is a functional element integral to ownership. If there is proven ownership of a feature demonstrated by possession, control, use, occupation and the likes, sovereignty is indubitably vested in that feature. Whereas ownership, and emanating from it, sovereignty are questions of law, the probative elements of possession, control and occupation are questions 
of fact. Needless to say, in circumstances such as in the subject arbitration, the proof of facts is predominantly that which is derived from historical evidence.

In international law jargon, sovereignty is the term as well as the legal concept that prevails in the context of sovereign states. It is essentially the corresponding equivalent of ownership, as it obtains both in terminology and as a legal concept in the private law sphere. Indeed, in the view of the present authors, the two phenomena of sovereignty and ownership are inextricably linked given that sovereignty emanates from ownership. Many rights of a sovereign state conferred by international law, through convention or custom, become entrenched in the law of the land by means of domestic legislation. In China, there are numerous pieces of legislation adopted to give effect to its rights under UNCLOS. Some that pertain to the present discussion are set out below.

One is the 1958 Declaration on China's Territorial Sea. In paragraph 1, after designating the 12-nautical mile territorial sea and naming several of the coastal islands surrounding Taiwan, it states "... and all other islands belonging to China which are separated from the mainland and its coastal islands by the high seas". In paragraph 4 of the same instrument, the phrase "all other islands belonging to China" is repeated. In the Law on the Territorial Sea and the Contiguous Zone, the words "... all other islands belonging to the People's Republic of China" are found in Article $2^{52}$. In this vein, attention must be drawn to the words "belonging to" (emphasis added) which clearly bear the connotation of ownership; namely, that "belong to" simply means "own". China's assertion of territorial sovereignty over these maritime features is unequivocally predicated on its ownership of these features. That assertion is clearly demonstrated by the legislation which is essentially a part of the national legal history.

The Tribunal did acknowledge that China's position concerned sovereignty over the islands and some other features in the South China Sea, and that it fell outside the scope of UNCLOS. It held the same view and stated that the matters which the Philippines brought to it for arbitration did not concern sovereignty. It declined to accept any proposition that because there was in existence a dispute over sovereignty, the claims submitted to it would ipso facto be given that characterization. Indeed, the Tribunal remarked repeatedly that the Philippines had not asked for any ruling on sovereignty, and that it was not about to do so. The needless overemphasis of the Tribunal points to its determination to avoid being misunderstood by China. It expressed its intention "to ensure that its decision neither advances nor detracts from either Party's claims to land sovereignty in the South China Sea"53. However it appears quite plainly that the Tribunal has in fact made oblique pronouncements on sovereignty by decidedly expressing its opinion on the legal status of various maritime features in the South China Sea.

On sovereignty, the observation of one author is reminiscent of the usefulness

\footnotetext{
${ }^{52}$ The legislation is excerpted in paragraphs 174 and 175 at pp. 68 and 69 of the Award.

${ }^{53}$ Paragraphs 153 and 154 at pp.58-59 of the Award. Presumably "land sovereignty" here refers to islands in light of the Tribunal's convoluted statements made in Paragraph 5 at p. 2 regarding the Spratly Islands and Scarborough Shoal.
} 
of conciliation as a non-binding process, albeit one that can only be used if there is no involvement of "disputed sovereignty over islands or land territory". Boyle, (1997) Regardless of the Philippines' position, from China's perspective, the dispute does involve sovereignty over "continental or insular land territory. According to scholars in the field, the Spratlys (Nansha Qundao) are without a doubt an insular feature; Symmons, (2014) and Scarborough Shoal (Huangyan) is evidently a continental feature, its seabed being "a part of the continental shelf naturally prolonging seawards from the coast” (Jia, 2014). The Tribunal has noted that UNCLOS is not concerned with "the sovereignty of States over land territory", and in that vein states it "has not been asked to, and does not purport to, make any ruling as to which State enjoys sovereignty over any land territory in the South China Sea, in particular with respect to the disputes concerning sovereignty over the Spratly Islands or Scarborough Shoal ${ }^{54}$.

It is conspicuous in the above passage is that the Tribunal purports to treat Spratly Islands and Scarborough Shoal as land territory, and in relation to that it has stated that "[N]one of the Tribunal's decisions in this Award are dependent on a finding of sovereignty, ..." ${ }^{\prime 5}$. The authors submit that the statement is misleading. In any event, determination of sovereignty is the primary issue in this dispute. In the words of an ICJ jurist, "[M]any maritime delimitation cases require the Court to decide, as a preliminary step, questions of sovereignty over disputed islands or certain coastal regions of land territory" (Shi, 2010). In essence, therefore, whether or not a feature is an island, a reef, a low-tide elevation, or a rock is of no significance until the issue of ownership, and flowing from it, sovereignty over the features, is resolved.

\section{Final Remarks and Conclusion}

Whereas the Tribunal has itself admitted that it has no jurisdiction to deal with the question of sovereignty over the features concerned, the Award is inundated with numerous pronouncements based on the submissions of the Philippines pre-empting any future resolution of the question of sovereignty over those features. As such, the Award is full of contradictions. The net result is that the Tribunal has pronounced on zonal issues pertaining to the mainland of China and whether and what zones and limits, the concerned features can generate under UNCLOS.

Finally, the Award is redundant because it is unenforceable. What matters from a practical point of view is how China views the Award. China's unwillingness to enforce it is surely an understatement. To what extent the stance adopted by the Philippines will actually materialize remains uncertain. The better way to resolve the disputed issues would be for both states to continue negotiations even if no final outcome can be anticipated at this stage. For China's part, it is evident from its published statements that settlement through peaceful

\footnotetext{
${ }^{54}$ Paragraph 5, pp.1-2 of the Award.

${ }^{55}$ Paragraph 5 at p. 2 of the Award.
} 
negotiation is the most sensible approach it continues to espouse in the wake of the arbitral ruling.

Even though it is by no means a conclusion foregone, hopefully, this contribution will aid in underscoring the need for an objective and unbiased approach to dispute resolution by tribunals in the field of international sea law. In the international arena, no arbitral or judicial decision is cast in concrete. State parties to a convention can overrule the interpretation of a provision given by a tribunal, by entering into a subsequent agreement providing a different interpretation or application; also such pronouncements can be reversed through state practice leading to customary international law (Talmon, 2017). The Vienna Convention on the Law of Treaties, provides that in interpreting a treaty, an international tribunal can take into account "any subsequent practice in the application of the treaty which establishes the agreement of the parties regarding its interpretation" (Vienna Convention on the Law of Treaties, 1155).

\section{Acknowledgements}

The opinions expressed in this article are entirely those of the authors and do not reflect any views of the institutions with which the authors are affiliated. The authors are grateful to Ms Guo Yujing, LLM student at Dalian Maritime University for her assistance.

\section{Conflicts of Interest}

The authors declare no conflicts of interest regarding the publication of this paper.

\section{References}

Allen, S. (2017). Article 297 of the United Nations Convention on the Law of the Sea and the Scope of Mandatory Jurisdiction. Ocean Development and International Law, 48, 313-330. https://doi.org/10.1080/00908320.2017.1325692

Boyle, A. E. (1997). Dispute Settlement and the Law of the Sea Convention: Problems of Fragmentation and Jurisdiction. The International and Comparative Law Quarterly, 46, 37-54. https://doi.org/10.1017/S0020589300060103

Chang, Y.-C. (2016). Taiwanese Position in the South China Sea Dispute: Before and after the Permanent Court of Arbitration Award. Journal of East Asia and International Law, 9, 467-468. https://doi.org/10.14330/jeail.2016.9.2.08

Chen, W. H. (2016). China Is Not Getting a Fair Shake, US Expert Says. The Manila Times, 30 June 2016.

https://www.manilatimes.net/2016/06/30/opinion/columnists/china-is-not-getting-a-fa ir-shake-us-expert-says/270962

Churchill, R. R., \& Lowe, A. V. (1999). The Law of the Sea (3rd ed.). Manchester: Juris Publishing, Manchester University Press.

Fu, K.-C. (2019). Misattribution of China's Historic Rights to the South China Sea by the 2016 South China Sea Arbitration (Part I). China Oceans Law Review, 2019, 14-32.

Glossary of Terms in Technical Aspects of Law of the Sea (TALOS), International Hydrographic Organization (IHO) Publication, 1982. 
Higgins, R. (1963). The Development of International Law through the Political Organs of the United Nations. London: Oxford University Press.

Hudson, M. O. (1944). International Tribunals. In World Court Reports. Washington DC: The Carnegie Endowment for International Peace and the Brookings Institution.

Jia, B. B. (2014). The Principle of the Domination of the Land over the Sea: A Historical Perspective on the Adaptability of the Law of the Sea to New Challenges. German Yearbook of International Law, 57, 1.

Jin, Y. M. (2017). The Impact and Influence of the South China Sea Arbitration on the Law of the Sea. China Legal Science, 5, 82.

Johnson, D. H. N. (1976-77). The ICJ Declines Jurisdiction Again (the Aegean Sea Continental Shelf Case). Australian Yearbook of International Law, 7, 309-331.

Kopela, S. (2017). Historic Titles and Historic Rights in the Law of the Sea in the Light of the South China Sea Arbitration. Ocean Development and International Law, 48, 181207. https://doi.org/10.1080/00908320.2017.1298948

Ma, X. M. (2018). Merits Award Relating to Historic Rights in the South China Sea Arbitration: An Appraisal. Asian Journal of International Law, 8, 12-23. https://doi.org/10.1017/S2044251317000236

Mukherjee, P. K. (2021). Mukherjee on Maritime Legislation. Malmo: WMU Publications.

Nordquist, M. H. (2016). Interview to Straits Times, Singapore. Reported by Tan Keng Tat under the Title "South China Sea: Did the Ruling Sink the Rule of Law?" https://www.straitstimes.com/opinion/did-the-ruling-sink-the-rule-of-law

Nordquist, M. H., Moore, J. N., \& Long, R. (2017). International Marine Economy: Law and Policy. Leiden: Martinus Nijhoff.

Nordquist, M. H., Nandan, S. N., \& Rosenne, S. (1989). United Nations Convention on the Law of the Sea: A Commentary (Vol. V).

Oxman, B. H. (2016-2017). The South China Sea Arbitration Award. University of Miami International and Comparative Law Review, 24, 235-284. https://doi.org/10.2139/ssrn.2835534

Reeder, J. (2011). Brice on Maritime Law of Salvage (5th ed.). London: Sweet \& Maxwell.

Rossi, C. R. (2017). Treaty of Tordesillas Syndrome: Sovereignty ad Absurdum and the South China Sea Arbitration. Cornell International Law Journal, 50, 231-283. https://doi.org/10.31228/osf.io/hy2nr

Schoenbaum, T. J. (2016). The South China Sea Decision: What Happens Next? JIML, 22, 291-303.

Shi, J. Y. (2010). Maritime Delimitation in the Jurisprudence of the International Court of Justice. Chinese Journal of International Law, 9, 271-291. https://doi.org/10.1093/chinesejil/jmq018

Starke, J. G. (1989). Introduction to International Law (10th ed.). London: Butterworths.

Status of Eastern Carelia, Advisory Opinion, 1923 P.C.I.J. (Series. B) No. 5 (July 23).

Symmons, C. R. (2014). Maritime Zones from Islands and Rocks. In S. Jayakumar, T. Koh, \& R. Beckman (Eds.), The South China Seas Disputes and Law of the Sea (pp. 55-90). Cheltenham: Edward Elgar Publishers.

Talmon, S. (2017). The South China Sea Arbitration and the Finality of "Final" Awards. Journal of International Dispute Settlement, 8, 388. https://doi.org/10.1093/jnlids/idw027

Tanaka, Y. (2012). The International Law of the Sea. New York: Cambridge University Press. 
Thayer, C. (2017). Dead in the Water: The South China Sea Arbitral Award, One Year Later. The Diplomat, No. 32, July 2017.

The Ministry of Foreign Affairs of the PRC (2014). Position Paper of the Government of the People's Republic of China on the Matter of Jurisdiction in the South China Sea Arbitration Initiated by the Republic of the Philippines. https://www.fmprc.gov.cn/mfa eng/zxxx 662805/t1217147.shtml

The State Council Information Office of the PRC (2016). China adheres to the Position of Settling through Negotiation the Relevant Disputes between China and the Philippines in the South China Sea.

http://www.china.org.cn/government/whitepaper/node 7239601.htm

United Nations Convention on the Law of the Sea, 1982, 1833 UNTS 3.

Vienna Convention on the Law of Treaties, 1155 UNTS 331.

Whomersley, C. (2017). The Award on the Merits in the Case Brought by the Philippines against China Relating to the South China Sea: A Critique. Chinese Journal of International Law, 16, 387-423. https://doi.org/10.1093/chinesejil/jmx023

Xu, H. (2016). Briefing on the South China Sea Arbitration Initiated by the Philippines. http://www.chinamission.be/eng/fyrih/t1362767.htm

Yee, S. (2014). The South China Sea Arbitration: Potential Jurisdictional Obstacles or Objections. Chinese Journal of International Law, 13, 663-739. https://doi.org/10.1093/chinesejil/jmu045

Yen, H. T. (2017). The South China Sea Arbitral Award: Legal Implications for Fisheries Management and Cooperation in the South China Sea. Cambridge International Law Journal, 6, 87-94. https://doi.org/10.4337/cilj.2017.01.06

Zhang, J. S. (2016). Neighbours Can Manage Their Differences. China Daily, Monday 25 July, 2016.

Zou, K. Y. (2016). Historic Rights in the South China Sea Arbitration Case-A Preliminary Reflection. Asia-Pacific Journal of Ocean Law and Policy, 1, 268-272. https://doi.org/10.1163/24519391-00102015

Zou, K. Y. (2017). Navigation in the South China Sea: Why Still an Issue. International Journal of Marine and Coastal Law, 32, 243-267. https://doi.org/10.1163/15718085-12322038

Zou, K. Y., \& Qiang, Y. (2017). Interpretation and Application of Article 298 of the Law of the Sea Convention in Recent Annex VII Arbitration: An Appraisal. Ocean Development and International Law, 48, 331, 332.

\section{Cases}

Anglo-Norwegian Fisheries Case (United Kingdom v. Norway) (1951), I.C.J. Rep. 116.

Bangladesh v. Myanmar, ITLOS Case No 16; 52014XC0830(01); ICGJ 448 (ITLOS 2012), 14 March 2012.

Costa Rica v. Nicaragua [2013] ICJ Rep 354; ICGJ 475 (ICJ 2013), 22 November 2013.

Greece v. Turkey, 1977 I.C.J. 3 (Dec. 19)

The Corfu Channel Case [1949] ICJ Rep 1.

The Grisbådarna Case (1909), XI RIAA 147. (Norway-Sweden).

The Tubantia (1887), 13 App. Cas. 160.

Tunisia v. Libya (1982), ICJ Reports 18. 